\title{
Governance changes in peri-urban farmland protection following decentralisation: A comparison between Montpellier (France) and Rome (Italy)
}

\author{
Coline Perrin $^{\mathrm{a}}$, Brigitte Nougarèdes ${ }^{\mathrm{a}, *}$, Laura Sini $^{\mathrm{a}}$, Paola Branduini ${ }^{\mathrm{b}}$, Luca Salvatiuca ${ }^{\mathrm{c}}$ \\ a French National Institute for Agricultural Research (INRA), UMR Innovation, Montpellier, France \\ b Politecnico di Milano, A.B.C. Department, PaRID Lab, Italy \\ c CREA Research Centre for Forestry and Wood, Viale di S. Margherita 80, Arezzo, I-52100 Italy
}

\section{A R T I C L E I N F O}

\section{Keywords:}

Agricultural land

Urban planning

Urban fringe

Social acceptability

Farm buildings

Innovation

\begin{abstract}
A B S T R A C T
Many countries have implemented laws and planning instruments to preserve farmland on the urban fringe. This paper aims at a better understanding of the governance changes in peri-urban farmland protection following decentralisation processes in France and Italy. We compare the implementation of farmland protection instruments in the two city regions of Montpellier and Rome. From a governance perspective, we highlight the practical issues of effectiveness and social acceptability arising from power devolution, different forms of governance, and the potential conflicts when planning control shifts to lower-than-regional bodies.

Our analysis is based on qualitative methods Primary data were collected through document analysis, participant observation and in-depth interviews aimed at understanding local stakeholders' practices and points of view on access to farmland, housing and building rights.

We find that around Rome and Montpellier, decentralisation has produced multiple decision-making authorities and increased the complexity of procedures. Despite more regulatory constraints in agricultural areas, farmland conversion has persisted. However, decentralisation processes have also changed ways of governing and favoured local alternative initiatives for farmland protection and farming development on the urban fringe. New modes of governance involve public local authorities, farmers' representative bodies (Montpellier) and civil society organisations (Rome). In both cities, they have a positive but limited impact on the effectiveness of farmland protection instruments. Their social acceptability varies, depending on who is really included in the participation process.
\end{abstract}

\section{Introduction}

Urbanisation is a global phenomenon with major implications for croplands worldwide (Bren d'Amour et al., 2016). Since the 1990s, a growing body of scientific literature has examined the urban conversion of farmland (Bryant and Johnston, 1992; Nelson, 1992) and its impacts on landscape, environment, and food security (Johnson, 2001; Plieninger et al., 2016). Many countries have accordingly implemented laws and planning instruments to preserve farmland on the urban fringe (Alterman, 1997; Bengston et al., 2004; Daniels and Lapping 2005). These studies identify various obstacles to effective farmland protection. Tan et al. (2009) in particular compare how national governance structures impact farmland conversion in the Netherlands, Germany, and China. They highlight major differences related to land ownership, land use planning, the role of the market and the role of government. However, they conclude that it is very difficult to assess and compare the performance of individual governance structures, each embedded in its local context. They therefore promote the "comparative study of institutional change stories" (p.973).

Our objective is, thus, to contribute to a better understanding of governance changes in peri-urban farmland protection following decentralisation by comparing the situation in France and Italy. These two nations have private property regimes with some use constraints (Jacobs, 2008). Since the 1970s, they have undergone a process of decentralisation that has affected the governance of land use planning decisions. In both countries, the land use planning system is based on binding zoning plans drawn up at municipal level. Their models of decentralisation, however, differ: France has a centralised tradition and Italy a tradition of local autonomy.

To shed light on the influence of such decentralised governance structure on agricultural land use planning, we compare the implementation of farmland protection instruments in the two city regions of Montpellier (France) and Rome (Italy). From a governance perspective, we aim to highlight the practical issues arising from power

\footnotetext{
* Corresponding author at: Brigitte Nougarèdes INRA-UMR Innovation - Bât. 27 2, Place Pierre Viala 34060 Montpellier, France.

E-mail address: brigitte.nougaredes@inra.fr (B. Nougarèdes).
} 
devolution, different forms of governance, and the potential conflicts when planning control shifts to lower-than-regional bodies.

Does the devolution of powers lead to different forms of governance of farmland protection? Do these governance forms affect the effectiveness and social acceptability of farmland protection instruments?

In what follows, we first explain our conceptual and analytical frameworks. Then, we provide an overview of our case studies and methods, and we compare land use planning systems in France and in Italy. In the results section, we focus on local practices to explain how peri-urban farmland protection has been implemented around Rome and Montpellier. Then, we present alternative local initiatives which illustrate new modes of governance involving not only public local authorities, but also farmers' bodies and civil society organisations. The last section discusses the impacts of decentralisation and of different modes of governance on the effectiveness and social acceptability of farmland protection instruments.

\section{Conceptual and analytical frameworks}

\subsection{Farmland conversion: forms and stakeholders}

Urban sprawl caused by the conversion of farmland to urban uses may follow various spatial patterns: from spill-over or leapfrog in dense urban developments (Yaping, 2009; Altes, 2009) to the low-density scattering of buildings within agricultural areas (Millward, 2006; Gosnell et al., 2011). Many driving factors explain these various patterns. Around the Mediterranean for example, Salvati (2013) shows that urban growth follows a path-dependency process: Rome and Lisbon, which had a dispersed urban form at the beginning of the 20th Century have experienced more sprawl than Athens and Barcelona, which had and still have a more compact form.

In this paper, we refer to various processes of farmland conversion:

- Farmland conversion driven by planning choices. This urbanisation is legal and produces new residential or commercial districts, following spill-over or leapfrog spatial patterns. New transportation infrastructures also cause fragmentation of farmland.

- Farmland conversion driven by individuals, for private projects, leads mainly to the scattering of residential and farm buildings within agricultural areas.

Since the 1960s, French and Italian governments have tried to control such long-term trends in farmland conversion, while, at the same time, the pattern of governance has shifted from predominantly centralised to more decentralised modes.

\subsection{A governance perspective revealing the impacts of decentralisation}

We propose to use a conceptual framework based on a governance perspective to focus not only on formalities (and government institutions) but also on governing behaviours and practices. With Stoker (1998), we believe that "the value of the governance perspective rests in its capacity to provide a framework for understanding changing processes of governing" (p.18). Kjær (2004) pointed out that 'governance' has different meanings for the people using it. Most scholars agree with Stoker that "governance refers to a set of institutions and actors that are drawn from but also beyond government" (1998, p.18). Since the 1980 s, in a context of public budget reductions, governance has evoked the stepping back of the state, the limits of government, and the growing commitment by individuals and civil society to tackling social and economic issues. This governance perspective "sees the government as able to use new tools and techniques to steer and guide" Kjær (2004), not only command in a top-down approach.

For this paper, we refer to Kooiman's 'interactive governance' framework (Kooiman, 2003) to analyse the interactions of social and political actors from state, market and civil society. Based on three types of interactions ('interferences' in primary societal processes, horizontal 'interplays', and vertical, formalized 'interventions'), he distinguishes three modes of governance: 'self-governance', 'co-governance' and 'hierarchical governance'. Moreover, Kooiman's interactive governance has three components: images, instruments, and action. 'Images' are visions, knowledge, convictions, ends and goals which guide action, may or may not be shared among stakeholders, and may or may not be explicit in public action. 'Instruments' link these images to action, to influence societal interactions (legal tools, incentives, etc.). A wide range of instruments is available, and they are not considered a neutral medium. 'Action' is how instruments are put into effect, for instance the implementation of policies according to set guidelines. These notions will be useful in our analysis to show the role played by instrumentation in farmland protection policies.

Decentralisation processes partly explain the shift from government to governance in France and Italy. According to the World Bank, "decentralisation is the transfer of authority and responsibility for public functions from the central government to intermediate and local governments or quasi-independent government organisations and/or the private sector". ${ }^{1}$ Schneider (2003) distinguishes three core dimensions: 'political', 'administrative' and 'fiscal' decentralisation.

Decentralisation is generally promoted by international organisations to provide better opportunities for local stakeholder participation in decision-making, aiming for more creative, innovative and responsive programs. However, frequent challenges in implementing decentralised governance include the potentially reduced efficiency of public action in regions with weaker administrative and technical capacities, a lack of strategic vision and an increased risk of corruption at local levels. The literature on land use planning highlights issues of timescale coordination (Holtslag-Broekhof et al., 2014), vertical coordination between multiple public decision-making levels (Koomen et al., 2008; Kline et al., 2014, Artmann, 2014), spatial coordination and balance between rural and urban authorities (Lichtenberg and Ding, 2008). Stakeholder-based approaches are complex to implement due to the high number and diversity of stakeholders involved, as well as their often antagonistic interests (Cormerais-Thomin and Bertrand 2013, Rey-Valette et al., 2014). They even raise issues of procedural and distributive justice (Kerselaers et al., 2013). That is why we decided to focus not only on effectiveness but also on social acceptability of farmland protection instruments and their modes of governance.

\subsection{Analytical framework: assessing effectiveness and social acceptability of modes of governance}

Farmland protection policies encompass public acquisition of land, regulatory approaches (urban growth boundaries, green belts, comprehensive zoning), and incentive-based approaches (based on taxation or on purchase or transfer of development rights) (Bengston et al., 2004). French and Italian farmland protection policies are characterised by the pivotal role of land use planning. We will see how decentralisation modifies the way land use planning is implemented, introducing new modes of governance of farmland protection. Our assessment of these various modes of governance will consider two dimensions: effectiveness and social acceptability.

The notion of effectiveness relates to the outcomes of public policy relative to its goal. We will thus consider farmland protection instruments as effective (i) if they reduce the rate of farmland conversion some urban sprawl is considered unavoidable during economic development and population growth periods -, (ii) if agricultural land is still actively farmed and (iii) if they help meet societal demands for a multifunctional peri-urban agriculture (Zasada, 2011) providing goods and services (landscapes, natural risk management, short food supply chains (SFSC), etc.).

\footnotetext{
${ }^{1}$ http://www1.worldbank.org/publicsector/decentralisation/what.htm.
} 
The notion of social acceptability encompasses, but is not reduced to, social acceptance. Working on wind energy projects, Fournis and Fortin (2017) call social acceptability the "field of possibilities opened by the interplay between society and technology, (...) encompassing both the diversity of possible paths of socialisation of technology and the specific results of a peculiar evaluation of a single wind project (acceptance/unacceptance)“ (p.14). Social acceptability is thus dynamic and socially constructed, taking into account public debates, civil mobilisation, negotiation and power relationships between stakeholders. Through this notion of social acceptability, we will study how farmland protection instruments are perceived and appropriated by stakeholders, examining whether they generate resentment. Implementing farmland protection instruments can trigger conflicts, often related on the urban fringe to the fact that the value of land - considered as a commodity on the market for urban development - is greatly reduced by local governments setting up exclusionary agricultural zoning. As there is no compensation under land use regulations in France and in Italy, landowners have often opposed local authorities since the 1970s (Renard, 1980; Cadène, 1990). But over the last 20 years, even more conflicts have been linked to place-based collective efforts to prevent or manage the negative impacts of urbanisation on agrarian landscapes. For instance, in the Greater Paris Region, Darly and Torre (2013) emphasize that grassroots initiatives, neighbourhood committees and NGOs involved in farmland protection movements are mainly driven by interests related not to agriculture but to the protection of local amenities. These conflicts are obstacles throughout the implementation of farmland protection instruments.

We will thus consider that an instrument is socially acceptable if (i) its allocative outcomes are considered as legitimate, complying with established rules and justifiable by reference to shared beliefs (Beetham, 1991) and if its implementation (ii) does not generate conflict or strong resentment and (iii) does not lead to the exclusion/ marginalisation of stakeholders.

\section{Local contexts and methods}

\subsection{Two mediterranean cities experiencing urban sprawl}

We examine farmland governance on the urban fringe around two Mediterranean metropolises: Rome (Italy) and Montpellier (France). We chose to compare these two cities because both have experienced strong population growth since the mid-twentieth century (Table 1), resulting in extensive expansion, mainly toward dispersed morphologies (Fig. 1) into surrounding rural areas (Abrantes et al., 2010; Salvati et al., 2012). Thus, the challenge of farmland conversion governance is strong in both city-regions. Rome and Montpellier also have socioeconomic similarities: urban growth has been based on residential and service sectors (especially tourism). Both cities have been very attractive for migrants from the rest of the country and from other European and Mediterranean countries. The cities differ in size. Rome is the capital of Italy and its largest municipality, with 2.8 million inhabitants. Montpellier Méditerranée Métropole includes the municipality of Montpellier, Francés eighth largest city, and 30 peri-urban municipalities with a total population of 450,000 inhabitants (Table 1). Nevertheless, we consider these two urban areas as paradigmatic cases of long-term socio-ecological interactions between urban growth and peri-urban agriculture along a population size gradient.

Both regions are representative of Mediterranean farming systems, with a significant shift to peri-urban multifunctional agriculture since the 1960s. The Montpellier region has a long history of wine production. Grape monocropping still occupies most agricultural areas, but since 1970 the wine industry has experienced repeated crises. Uprooted vineyards have left space available for the diversification of peri-urban agricultural production (cereals, vegetables) (Perrin et al., 2013). Land tenure is very fragmented amongst private smallholders.

Since the Roman era, land around Rome (the 'Agro Romano') has been considered one of central Italýs most fertile farmlands, with good soil conditions created by the recurring floodtides of the river Tiber. After the Second World War, extensive crops (mainly wheat, olives and vineyards) outnumbered intensive irrigated crops. Land was mainly owned by the Catholic church, the State, local authorities and a few other large private landowners. Significant changes over the last two decades include increased land fragmentation from urban sprawl and decreasing numbers of farms: urbanisation helped push smallholders out of production (Cavallo and Marino, 2012).

\subsection{Methods: document analysis, participant observation and in-depth interviews}

This paper is based on qualitative methods. Primary data were collected through document analysis (laws, land-use planning documents, other policy documents, local newspapers), in-depth interviews and participant observation.

The fieldwork in Rome was conducted over four months in 2015 for a Masteŕs thesis (Sini, 2015) and included 37 interviews plus observation of a 3-day participatory workshop for the implementation of an agricultural park. The fieldwork in Montpellier was based on more than 100 interviews conducted for a $\mathrm{PhD}$ thesis (Nougarèdes, 2013), on participatory observation of regular meetings and working groups involving government and farmers' representative bodies from 2004 to 2011 (about once a month), and on several case studies of alternative local farmland protection initiatives between 2008 and 2015.

Table 1

Population and agriculture characteristics in Rome and in Montpellier Méditerranée Métropole.

\begin{tabular}{|c|c|c|}
\hline & Rome municipality & $\begin{array}{l}\text { Montpellier Méditerranée Métropole ( } 31 \\
\text { municipalities) }\end{array}$ \\
\hline Population & $2722400(2011)$ & $434100(2012)$ \\
\hline Population growth (last 10 years) & $9.6 \%$ & $13.8 \%$ \\
\hline Total surface, $\mathrm{km} 2$ & 1285 & 439 \\
\hline Density (inhab/km2) & 2120 & 988 \\
\hline Agricultural area $(\mathrm{km} 2)$ & $433(2010)$ & $141(2008)$ \\
\hline Decrease in agricultural area & $-17 \%(1990-2010)$ & $-13.3(1994-2008)$ \\
\hline Number of farms & $2656(2010)$ & $640(2010)$ \\
\hline \multirow[t]{5}{*}{ Types of farms } & Family farms, 16 ha on average & Family farms, 22 ha on average \\
\hline & $29 \%<1$ ha; & $23 \%<1$ ha; \\
\hline & $45 \%$ within $[1-10 \mathrm{ha}[$ & $41 \%$ within $[1-10$ ha [ \\
\hline & $18 \%$ within $[10-49.9$ ha [ & $29 \%$ within $[10-50 \mathrm{ha}[$ \\
\hline & $8 \%>50$ ha & $7 \%>50$ ha \\
\hline Decrease in number of farms & $-38.3 \%(1990-2010)$ & $-41 \%(2000-2010)$ \\
\hline Main agricultural products & Cereals, grapes, olives, fodder, dairy, vegetables & Grapes, cereals, fodder, sheep \& goats, vegetables \\
\hline Land tenure & $\begin{array}{l}\text { Dual land tenure, big public (State }+ \text { municipality) and Church estates plus individual } \\
\text { farmers (small farms) }\end{array}$ & $\begin{array}{l}\text { Dominance of small private farmer-owned } \\
\text { properties }\end{array}$ \\
\hline
\end{tabular}




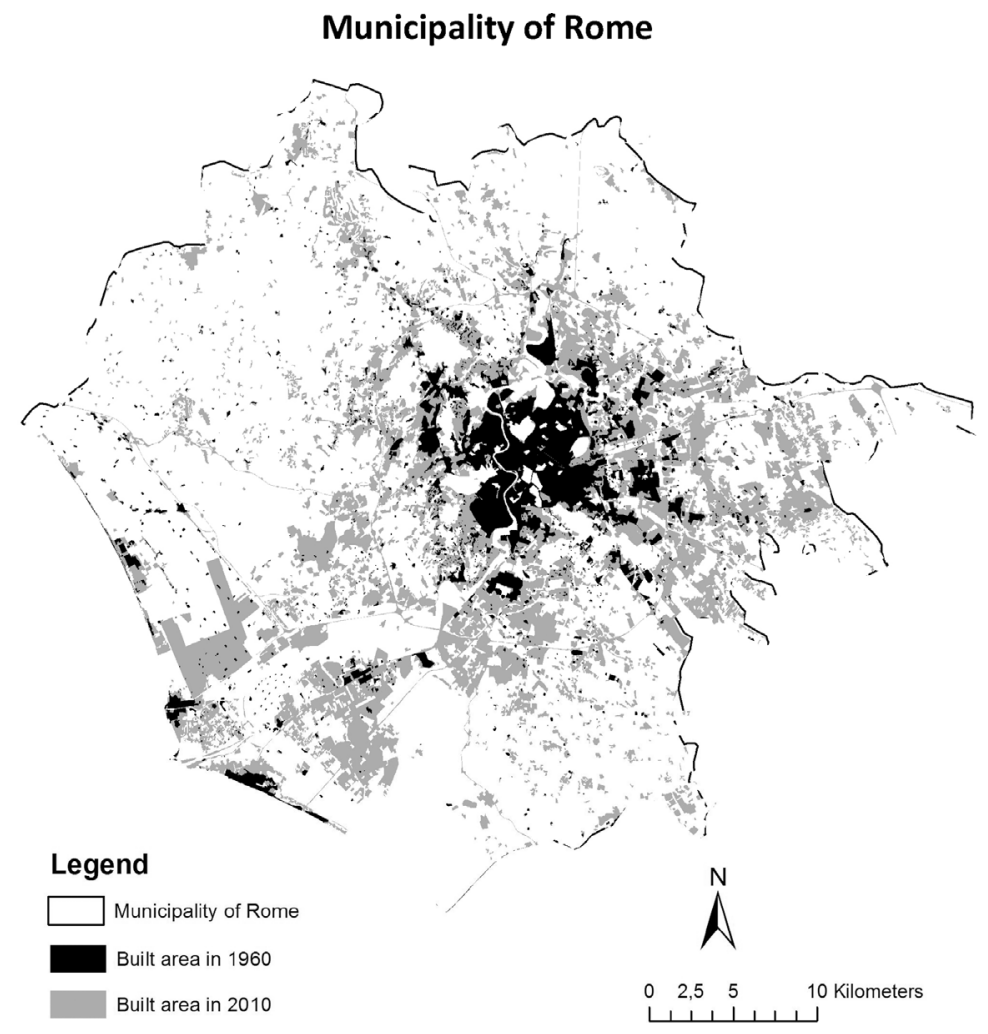

Fig. 1. Urban sprawl in Rome and around Montpellier between 1960 and 2000.

\section{Montpellier Méditerranée Métropole}
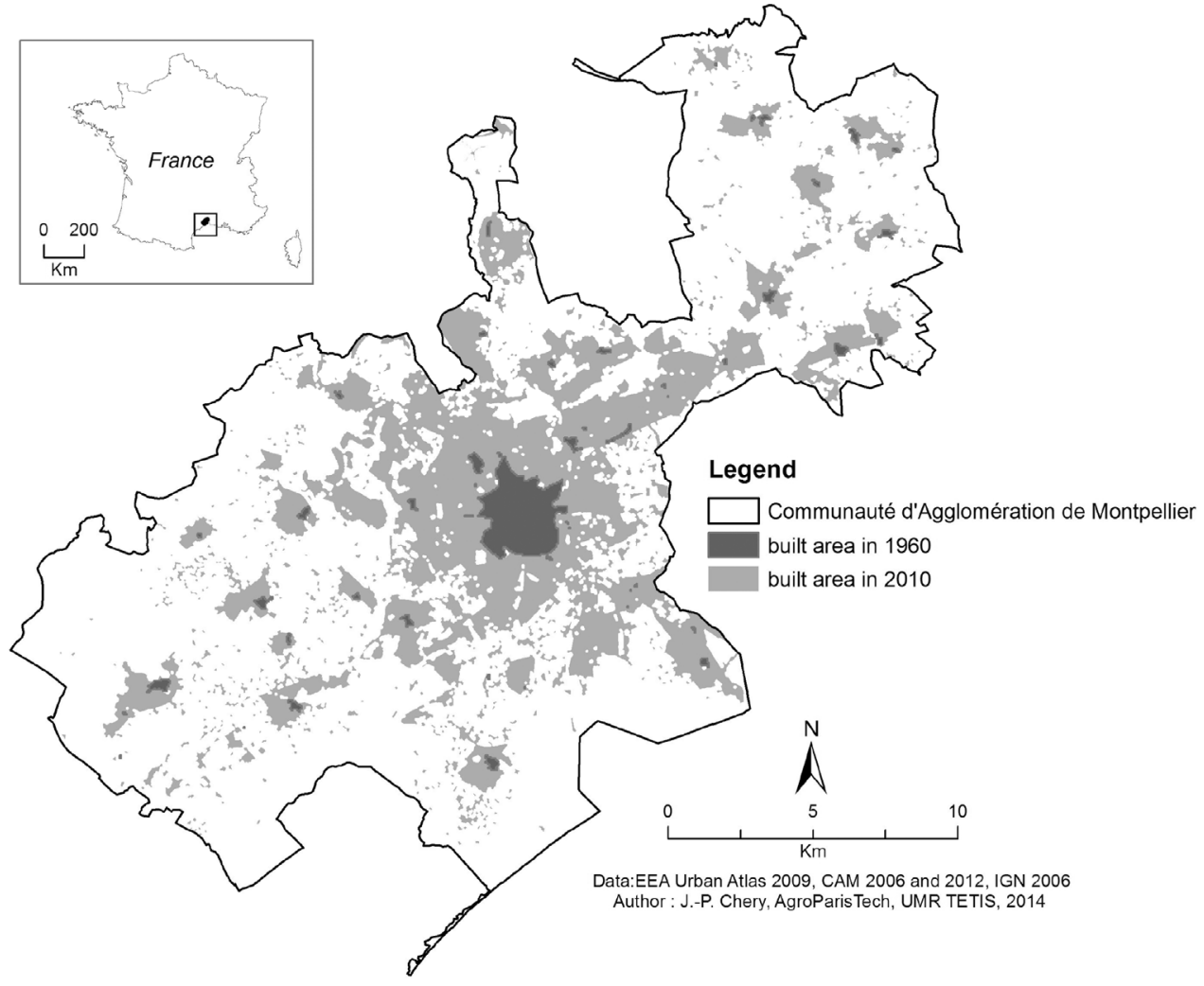

We first interviewed government officials and staff responsible for the implementation of land use planning at local levels (municipality, region and province (Italy), or département (France)) and a sample of farmers representating the local farming systems. Then, through the document analysis, the participant observation and these first interviews, we identified alternative local initiatives aimed at protecting farmland and conducted further interviews with the largest possible range of stakeholders representing various interests (farmers, residents, 
Table 2

Role of administrative levels of government in land use planning.

\begin{tabular}{|c|c|c|}
\hline Level of government & Italy & France \\
\hline Central State & Law of 1942 & All laws are national \\
\hline \multirow[t]{3}{*}{ Regions (20 in Italy/18 in France) } & Urban and rural planning laws & $\begin{array}{l}\text { Strategic planning guidelines (general objectives and } \\
\text { orientations) }\end{array}$ \\
\hline & $\begin{array}{l}\text { Strategic planning guidelines (binding regional } \\
\text { coordination plan) }\end{array}$ & \\
\hline & Control of municipal zoning plans & \\
\hline $\begin{array}{l}\text { Provinces (110 in Italy)/Départements (101 in } \\
\text { France) }\end{array}$ & Not a significant role in land use planning & $\begin{array}{l}\text { Interpretation of national laws, control and advice to } \\
\text { municipalities }\end{array}$ \\
\hline Metropolitan areas (14 in Italy/15 in France) & Strategic planning guidelines & $\begin{array}{l}\text { Growing role since laws of } 1997 \text { and } 2014 \\
\text { Intermunicipal master plans }\end{array}$ \\
\hline Municipalities (7983 in Italy/35,416 in France) & Draw up binding zoning plans & Draw up binding zoning plans \\
\hline
\end{tabular}

government officials and staff, farmers' organisations, NGOs).

All interviews were recorded and transcribed. Their purpose was to understand local stakeholders' practices and points of view on policies and local initiatives affecting access to farmland, housing and building rights in peri-urban agricultural areas. First, the interview elicited their knowledge of current and past farmland protection policies or local initiatives. We next focused on their personal opinion of such instruments: objectives (legitimacy), implementation (procedures, inclusion/ exclusion of stakeholders in participation), and consequences (impacts on farmland conversion, social conflicts or personal resentments). The content of the discourse and the documents was then processed within a common analytical framework structured around Kooiman's elements of governance (images, instruments, actions) and the stakeholders' perceptions of the effectiveness and social acceptability of farmland protection instruments.

\section{Legal frameworks for farmland protection in France and Italy}

In this section, we provide a short overview of legal 'instruments' for farmland protection. In Rome and Montpellier city-regions, local authorities control urbanisation by planning land use within the framework of decentralised governance.

\subsection{A progressive decentralisation of land use planning systems}

In Italy and in France, the planning system is structured in a hierarchical pyramid fashion (Table 2), leading to multilevel governance. Public regulation of urban planning mainly relies on binding zoning plans drawn up at municipal level. These plans define urban zones, zones to be urbanised and zones to be protected (rural zones in Italy, agricultural and natural zones in France). The municipal councils approve the plans and mayors sign building permits.

Important differences between the two countries relate to how municipalities are controlled. In France, legislative power, supervision and control are still in the hands of the central State, with increasing input from intermunicipal authorities (metropolitan level). In Italy, the State created an initial legislative framework in 1942, but since 1970 has delegated all legislative and executive powers regarding urban and regional planning to the Regions. Relations between the various decision-making levels are governed by regional plans.

\subsection{Urban planning regulations in agricultural areas have been reinforced}

Farmland protection is today considered a public goal: in France $\left(2010^{2}\right)$ and in Italy $\left(2016^{3}\right)$, state governments have committed to reducing farmland conversion. This goal represents the 'image'

\footnotetext{
${ }^{2}$ The law 2010-874 on Modernisation of Agriculture and Fisheries sets the goal of halving conversion of farmland between 2010 and 2020 .

${ }^{3}$ The Italian law 2016/2383 on reduction of farmland conversion sets the goal of halting conversion of agricultural areas between 2016 and 2050
}

(Kooiman, 2003) guiding public action. Since the end of the 1990s, both countries have strengthened protection of agricultural land through regulatory constraints (Table 3 ).

In France, since 2000, only buildings essential to (and no longer merely related to) farming are authorised. In Italy, regulations on buildings in rural zones used to be based on plot size, with no required link with agriculture. The 1970 regionalisation resulted in each region issuing its own planning law, so the criteria governing buildings in rural zones differ from region to region. In Latium, the region where Rome is located, since 1999, only farmers can build in rural zones under regulations that are very similar to the French (Table 3).

However, Italy's position regarding landscape, architectural and archaeological stakes adds bureaucratic procedures. Since 2004 (D.L.42), the Landscape Report (Studio di Inserimento Paesistico, SIP in Latium, different names in different regions) has been required for a building permit. This document demonstrates the compatibility of the project with State law, regional and/or other landscape plans, like regional parks (Scazzosi and Branduini, 2014).

Thus, in both nations, planning regulations have been reinforced in agricultural zones. The first local zoning plans of 1960-70 mainly framed residential urban developments, but for the last fifteen years, agricultural buildings have been regulated equally tightly. Evaluation tools are more sophisticated in Rome (PUA, SIP, building permits) than in Montpellier (a simple building permit with a landscape section). In France, the focus is on the size of urbanised agricultural areas and less on architectural and landscape considerations. These two land use planning systems correspond to what Kooiman names "hierarchical governance", "a top-down style of intervention, expressing itself in policies and law" (Kooiman et al., 2008: 9).

\section{Results}

Having presented the legal 'instruments' for farmland protection, we will now focus on local 'actions' (Kooiman 2003). The first section (5.1.) describes the challenges involved in implementing these regulations in agricultural areas under decentralised governance, attempting to explain a paradox: the persistence of farmland conversion despite reinforced planning regulations. The second section (5.2.) presents alternative local initiatives for protecting farmland and maintaining farming on the urban fringe. We assess the effectiveness and social acceptability of farmland protection instruments in both sections.

\subsection{Local implementation of farmland protection regulations:} decentralisation has lowered the effectiveness and social acceptability of a hierarchical mode of governance

Both in Montpellier and in Rome, decentralisation originally favoured urbanisation of farmland, whether by legal or illegal construction. However, the response in terms of public action differed: the French State is striving to regain control, whereas in Italy, the pursuit of illegal practices may be a reaction to an all-pervading bureaucracy. 
Table 3

Urban planning regulations in agricultural areas and decentralisation of land-use planning systems in France and Italy.

\begin{tabular}{|c|c|}
\hline France & Italy \\
\hline \multicolumn{2}{|l|}{ Before 1967: unregulated construction in agricultural areas } \\
\hline \multirow[t]{2}{*}{$\begin{array}{l}\text { 1967: Loi d'Orientation Foncière - LOF national land law. Only buildings related to } \\
\text { farming are authorised in agricultural zones. }\end{array}$} & $\begin{array}{l}\text { 1967: The national Ponte law institutes building permits in rural zones and establishes a } \\
\text { maximum buildable volume of } 0.1 \mathrm{~m}^{3} / \mathrm{m}^{2} \text {. }\end{array}$ \\
\hline & $\begin{array}{l}\text { 1968: A ministerial decree (DM 1444) restricts the maximum buildable volume in rural } \\
\text { areas to } 0.03 \mathrm{~m}^{3} / \mathrm{m}^{2} \text {. }\end{array}$ \\
\hline $\begin{array}{l}\text { 2000: National law on urban solidarity and renewal (loi SRU solidarité et renouvellement } \\
\text { urbains). Only buildings « essential to farming » are authorised in agricultural } \\
\text { zones. }\end{array}$ & $\begin{array}{l}\text { 1999: In Latium, regional law LR38 authorises the construction of } 0.04 \mathrm{~m}^{3} / \mathrm{m}^{2} \text { of farm } \\
\text { buildings and } 0.01 \mathrm{~m}^{3} / \mathrm{m}^{2} \text { of private housing. Housing must not exceed } 300 \mathrm{sq} . \mathrm{m} \text { and } \\
\text { must be built on a plot of over one hectare. }\end{array}$ \\
\hline $\begin{array}{l}\text { The permit requester must have farmer status and demonstrate the economic viability } \\
\text { of the farm and that the buildings are required for the farming activity. }\end{array}$ & $\begin{array}{l}\text { The permit requester must have farmer status and show evidence of a farm utilisation } \\
\text { plan (Piano di Utilizzazione Aziendale), a sort of business plan demonstrating the } \\
\text { economic viability of the farm and that the buildings are required for the farming } \\
\text { activity. }\end{array}$ \\
\hline
\end{tabular}

\subsubsection{Frequent revisions of municipal zoning plans and informal building} practices

Formal planning choices have the greatest impact on farmland conversion. Decentralisation has led both French and Italian municipalities to revise zoning plans frequently, enlarging or adjusting buildable zones to allow for public or private urban developments (Gibelli and Salzano, 2006). Our investigation shows how such public practices have impacted social acceptability. In Rome, farmers and residents interviewed were indignant at the administrations practices. The manager of a farmers' cooperative denounced the deals with real estate promoters: "they are the true masters of Rome, because elected representatives change but developers stay. They are very powerful and have a great influence on the administrations". In Montpellier, a representative of a farmers' union deplored "the agricultural zone reduction that follows each revision, to allow for tourist projects, infrastructure works or commercial districts". As found by Jarrige et al. (2003), our investigation confirms that this zoning instability favours real estate speculation on agricultural land, the development of fallows and withholding by owners, who refuse to sell or rent to farmers, waiting instead for their plot to become buildable. This instability thus weakens farmland protection.

The second factor affecting farmland conversion is the behaviour of landowners. The agricultural zones of both regions show evidence of the same building practices, on the fringes of legality, by non-farmer residents and farmers.

Non-farmer residents have built illegally in agricultural zones. Around Montpellier, fishing and farm sheds or mobile homes have been transformed into villas without authorisation (Crozat, 2009). In agricultural zones, we discovered both from technical staff at the Départements and from our analysis of building permits that permits have been granted to fictional farming projects designed to obtain the permit but having no economic reality. Local elected officials told us that these schemes take advantage of mayorś lack of farming knowledge, of the pressure owners can exert on mayors and of the State's inability to properly enforce regulations in a context of reduced budgets and public policy reform.

Around Rome, too, many buildings have been constructed without permits since the 1960s. Informal districts fragment the Agro Romano (Vallat, 1995). This practice was encouraged both by Italian government amnesties for urbanisation infringements in 1985, 1994 and 2003 and by the Piano casa in 2009. Our study shows that such behaviour continues in agricultural zones. Non-farmer owners regularly build without authorisation. One interviewee's construction of two villas was halted three times by the police and taken to court. To quote a neighbour: "The owner was supposed to destroy everything. But nothing happens. The price differential between farmland and buildable plots explains these illegal building practices. The fine costs more than the permit, but, after building, the property has a far higher value". Municipalities are supposed to destroy and sanction such buildings, but they only do so on exceptional occasions, hence losing their legitimacy.
Lastly, farmerś own building activities contribute to urban sprawl. Around Montpellier, technical staff at the Département told us that farmers sometimes rent or sell their houses to non-farmers and then obtain a permit for a new house for themselves. Around Rome, the PUA (farming business plan) does not always prevent changes of purpose for buildings. Accommodation for the daughter of a wine maker was presented in a PUA as farm management offices. According to a municipal official, farmers "obtain authorisation for agricultural buildings and then develop in them activities not linked to agriculture". Owners also pass themselves off as farmers: "they are members of the farmers' union Coldiretti, but in reality they have other activities". Such free riders show that all landowners - farmers or not - are aware of farmland's urbanisation potential, as a market commodity and not as a production factor for farming or a natural resource to be protected.

Evasive practices are thus very similar in both countries. They involve the same interplay between local officials, landowners, economic actors, prospective homeowners and farmers. They illustrate the difficulties local authorities face in enforcing policies intended to protect agricultural land. These public and private practices skirting the law not only reduce the effectiveness of farmland protection instruments but also lead to a loss of legitimacy and social acceptability of planning regulations.

Faced with this situation, the French State is striving to regain control; in Italy, lack of control is favouring the pursuit of illegal practices.

\subsubsection{Montpellier: the attempt to restore state control engenders conflict with farmers}

In France, the central State, with its strong centralising culture, is caught in a 'schizophrenic' posture.

On the one hand, the central State has attempted to regain control. It adopted stricter regulations in the national SRU law (2001). Around Montpellier, during our observation of a series of meetings of a working group composed of farmers' unions and Département offices supervising land use planning, farmers complained that mayors have become very reluctant to approve any building permits in agricultural zones, even for farming purposes. They pointed out that these new restrictions are a barrier to maintaining farming. Thus this sanctuarisation of agricultural areas, while protecting farmland, has lowered the social acceptability of farmland protection because it has triggered conflicts between State offices, municipalities and farmers.

On the other hand, within the framework of decentralisation, the central State is progressively losing direct control over local zoning plans and building permits, by delegating appraisal and control to municipalities and intermunicipal bodies. Using document analysis, we compared the interpretation of regulations between départements and between municipalities. We observed that in some départements/municipalities, almost all farmers can build housing provided their farms are economically viable, while in others, only farmers who have to supervise animals or food processing activities can build housing. The 
interviews showed that such differing applications of the law anger farmers and give rise to feelings of injustice. For example, farmers in a municipality which forbids new construction in the agricultural zone complained that other farmers in the surrounding municipalities are still authorised to build for farming purposes. Farmers also complain that they are considered scapegoats regarding urban sprawl, which they attribute mainly to residential development. A wine grower located close to a residential district explains: "It isn't the farmer who is most dangerous in terms of scattering. It's the prospective homeowner who buys a piece of land with only a small farm shed in poor condition. A few months later, he's making major extensions and turning it into a new house".

The decentralisation of a hierarchical mode of governance has thus weakened the social acceptability of farmland protection regulations: new inequalities in farmers' access to building rights have reduced the legitimacy of the 'image' of farmland protection, and created resentments, conflicts and exclusion.

\subsubsection{Rome: inadequate public action encourages continued evasive practices and conflicts}

Around Rome, farmers and civil society express a feeling of powerlessness and injustice faced with proliferating regulations, the administration's inability to ensure that they are respected and cases of preferential treatment. These shortcomings in public action legitimise continued evasion by landowners.

Citizens above all object to the blank cheques given to certain people by the administration. They feel that the way their requests for building are treated depends on their relationships, financial resources and political contacts. A Rome municipal official from the heritage protection department admitted that "the right hand does not know what the left is doing ...because there are interests in not blocking certain urban projects by means of regulatory constraints".

Shortcomings in public action are also due to complicated administrative processes. Obtaining a building permit requires hiring experts to draw up technical-economic and landscape assessments for the PUA and the SIP, potentially unaffordable for small farmers. The administrative process is often presented as an obstacle course, and response time is not compatible with an agricultural project. As stated by a wine grower: "it takes months, even years, to obtain the go-ahead from several administrative authorities".

Administrative delays incite farmers to get around the rules to develop their activities, and legitimise this. One farmer working 130 ha of cereals and fruit and vegetables south of Rome explained: "I lost more than three years in procedures, so I gave up. (...) We built everything we needed for farming" (without a permit). Ten years later, "to regularise, we presented a project with an extension. Since we had to go through a regularisation procedure, we decided we might as well do a good job, and for our children's sake too". "And we paid the fine. In the end, that is all that interests the municipality". Several owners thus told us that they had chosen to build without a permit and pay the subsequent fine to obtain regularisation. Some had even informed the mayor before starting to build without permits.

Thus, in both countries, decentralisation has fostered significant farmland conversion, lowering the effectiveness and the social acceptability of a hierarchical governance of farmland protection.

\subsection{Alternative local initiatives for protecting farmland and maintaining farming: towards new modes of governance}

The issues raised by the hierarchical mode of governing construction within agricultural areas have favoured the emergence of new modes of governance through alternative local initiatives for protecting farmland and maintaining farming on the urban fringe. We now assess the effectiveness and social acceptability of such initiatives led by the public sector in Montpellier and boosted by civil society in Rome.
5.2.1. In montpellier, co-governance between local authorities and representatives of the most powerful farmers improved effectiveness but not social acceptability

Around Montpellier, public actors have introduced new instruments to better protect farmland within a new mode of 'co-governance'. According to Kooiman et al. (2008), this mode covers a variety of configurations in which "societal parties join hands with a common purpose in mind (...). It implies the use of organised forms of interactions for governing purposes" (p.9), such as communicative governance, public-private partnerships, networks, regimes and co-management. In our case, local authorities co-managed periurban farmland through horizontal interplays with major farmers' unions at the département, metropolitan and municipal level.

At département level since 2004, the State has created around Montpellier a working group to discuss with farmers urban planning issues in agricultural areas. This initiative was extended to all départements in 2008 and subsequently institutionalised in 2010 under formal département regulation authorities (CDPENAF, ${ }^{4}$ ). In Montpellier, we noted during our observations that negotiations were dominated by the wine-growing sector. In an official document ${ }^{5}$ the working group interpreted the national regulations in their favour: only wine-makers and livestock farmers are allowed to build housing in agricultural zones. Representatives of other agricultural sectors, especially fruit and vegetables, tried unsuccessfully in 2010 to modify the agreement, and this caused resentment among farmers. A market gardener told us in 2016: "I have the feeling the mayor favours wine growers. Only wine growers obtain building permits and not the other farmers." Thus, while the département working group did help reduce farmland conversion and strengthen the legitimacy of regulatory constraints among local authorities and leading farmers' unions, it excluded some types of farmers. This did not help peri-urban agriculture move towards multifunctionality (Table 4).

At metropolitan level, the 2006 master plan framing municipal zoning (SCOT, Schéma de Cohérence Territoriale) addressed agricultural areas in a new way, not only as empty spaces awaiting urbanisation. Farmland protection became a major objective, a decisive argument for curtailing urban sprawl. The plan clearly outlines the areas for future urbanisation and agricultural areas are the subject of strict regulatory constraints to avoid sprawl. The 31 member municipalities were obliged to comply and revise their zoning plans accordingly. The SCOT reflects a hierarchical mode of governance at metropolitan level (Table 4), imposing the halt in urban sprawl by top-down management. It was effective in reducing the rate of farmland conversion and was socially accepted, but it involved very little consultation with the public and farmers' organisations.

In 2010, the metropolis created an agricultural park (agripark). It purchased a former wine estate, aiming to combine agricultural and forest production, environmental services (protection against natural risks) and citizens' recreational activities. Multifunctional agriculture was intended to enhance the sustainability of the urban project as stated by the Agenda 21 document (2011). This agripark was effective in farmland protection (Table 4): it preserved 200 ha from conversion, it allowed abandoned land to return to cultivation and introduced new farming systems (two market gardens). However, we show elsewhere that the lack of public consultation and transparency reduced its legitimacy and excluded potential candidates for tenancy (Jarrige and Perrin, 2017). This is a case of governance through co-management having poor social acceptability. Farmers renting land were not selected in accordance with multifunctional objectives but via a network of

\footnotetext{
${ }^{4}$ Commission départementale de la préservation des espaces naturels, agricoles et forestiers (département commission for the preservation of natural, agricultural and forest lands).

${ }^{5}$ Groupe de Travail Agriculture et Urbanisme de l'Hérault, 2005. Parcours à la construction agricole, 30 p. Revised in 2011: http://www.herault.gouv.fr/content/download/ 7510/41196/file/ParcoursConstructionAgricole.pdf
} 
institutional actors: farmers' organisations, political networks. Unequal allocation of land and building rights caused resentment among farmers involved in the project.

At municipal level, finally, mayors proposed to group new agricultural buildings to avoid their dispersion within agricultural areas. We showed previously that various formulae were tested in different towns (Nougarèdes, 2015). The principle of grouping was promoted by the departmental working group, included in the 2006 Montpellier SCOT and continues to spread throughout the country.

This principle of grouping effectively promotes farmland protection: it prevents the scattering of farm buildings while maintaining building rights for farmers. However, around Montpellier, this grouping of farm buildings was generally implemented under 'co-governance' between local farmers and the municipality. Our interviews reveal that this 'cogovernance' raised social equity issues and feelings of injustice both among farmers who were excluded (new farmers) and non-farmers struggling to obtain housing. Moreover, in some cases, lack of coherence between image (objectives) and action undermined the legitimacy of these policies.

5.2.2. In Rome, a move towards self-governance by civil society to promote multifunctional peri-urban agriculture improved effectiveness and social acceptability

Around Rome, we present three alternative local initiatives for protecting farmland and maintaining farming on the urban fringe, representing various modes of governance: hierarchical, co- and selfgovernance (Table 5). While around Montpellier, the initiatives emerge from negotiations between public actors and the leading farmers' unions, around Rome they emerge from the mobilisation of civil society and illustrate the public's new interest in agriculture.

First, the regulatory protection of the Agro Romano was reinforced through hierarchical governance. The revision of the capitals zoning plan led to vast protected environmental areas (Piano delle Certezze signed in 1997), three agricultural parks and stricter regulatory constraints in the Agro Romano (municipal binding zoning plan of 2008). Several areas designated for future urbanisation (ambiti di riserva) in agricultural areas were cancelled between 2013 and 2015. These land use planning policies show a new public will to protect farmland. Like the SCOT in Montpellier, they strengthened existing farms. However, several interviewees were concerned about whether the municipality would be able to enforce public control, avoiding preferential treatment and illegal building. The new regulatory constraints also triggered some conflicts with developers, even though landowners were compensated through the transfer of their development rights to other areas. Nevertheless it represented an improvement in the effectiveness and social acceptability of farmland protection instruments.

Second, public land ( 450 ha) was attributed in 2014 by the Rome municipality and the Latium region to young aspiring farmers, committed to the environment, social inclusion and recreational uses. Tenders for projects were organised because of public pressure, in particular by a co-operative of young unemployed workers during the municipal elections of 2013 (Di Donato et al., 2016). This allocation of public land is a mode of co-governance, because of the role played by this co-operative during the procedure. It was effective, allowing abandoned land to return to cultivation and contributing to the multifunctionality of peri-urban agriculture. As for social acceptability, some non-beneficiary farmers criticised the dominance of the co-operative in defining the selection criteria and thought that some chosen farmers' profiles were not fully consistent with these criteria.

Third, agricultural parks were included in the PRG of 2008 but have not yet come into being. The case of the Casal del Marmo agricultural park is almost a mode of self-governance, "situations in which actors take care of themselves, outside the purview of government" (Kooiman et al., 2008: 9). It was during public local consultations - urban planning conferences organised by each Rome district in the autumn of 2014-that the Casal del Marmo agricultural park became a concrete 
project. A participatory workshop organised in 2015 through EU financing brought together some fifty people over three days for field visits and thematic round tables. The goal was to foster dialogue between various interests and to build a common vision, a shared project for the park (Pellegrino and Marino 2016). These encounters demonstrated the relevance of the agricultural park as a tool for reconnection between city and agriculture and for social cohesion. Through this participatory process involving a large range of stakeholders, the agricultural park gained effectiveness and social acceptability. It not only avoided the urbanisation of 460 ha and strengthened farming since 2008, but may also promote multifunctional agriculture in line with the societal needs of city dwellers and the will of the stakeholders. However, it is not certain that the project as conceived during the workshop will become reality, in the absence of a specific budget and dedicated human resources for activation by the municipality. We see in this case the limits of self-governance if it depends on public funding.

\section{Discussion: ambivalent effects of decentralisation and new modes of governance on the effectiveness and social acceptability of farmland protection}

Many countries have implemented laws and planning instruments to preserve farmland on the urban fringe. However, it is difficult to assess the influence of individual governance structures, because each is embedded in its local context (Tan et al., 2009). This paper has addressed this issue by comparing the implementation of farmland protection instruments in the two city regions of Montpellier and Rome. Our hypothesis was that decentralisation processes have changed ways of governing, introducing new modes of governance that have had an impact on the effectiveness and social acceptability of farmland protection. From a governance perspective, our results highlight the practical issues arising from power devolution and different forms of governance relating to farmland protection on the urban fringe.

Decentralisation first fostered significant farmland conversion, lowering the effectiveness and the social acceptability of a hierarchical governance of farmland protection. We showed that around Rome and Montpellier, decentralisation has led to multiple decision-making authorities and has increased the complexity of procedures. Hierarchical governance has thus shown its limits: increased regulatory constraints have not prevented urban sprawl and scattering on farmland. Our investigation reveals that this scattering is due to legal and illegal construction by farmers and non-farmer residents, in both cases. This finding complements prior studies demonstrating (Madeline, 2006) and explaining (Perrin, 2015) why farm buildings account for a significant share of farmland conversion in France.

In addition, we showed that the devolution of planning powers to local authorities has worsened free-rider behaviour, skirting the law and preferential treatment by the authorities, due to the increased proximity of decision-makers and applicants for building permits. Pressure from development interests is even stronger when decisionmaking is local. This is a general tendency: Nelson and Moore (1996) stated that "when left for local implementation, state policies are often ineffectively implemented. The reason is that local officials are reluctant to counter prevailing development patterns or frustrate local citizens and interest groups" (p.242). They are more inclined to sidestep the legal framework or state policy goals (Jouve and Vianey, 2012; Cormerais-Thomin and Bertrand, 2013). French municipalities are at a disadvantage here, being generally smaller than Italian municipalities but land use decisions are exposed to manipulation and corruption in both Montpellier and Rome. Local authorities' actions are not always consistent with the national goal (Kooiman's 'image') of farmland protection. This situation is not specific to France and Italy. In Israel, Alfasi et al. (2012) denounce a case-by-case "discretionary-oriented decision-making, providing for revisions of the land use plans and subsequently diminishing its efficacy" (p.862). Since the 1980s, farmland preservation has often been analysed as a matter of local politics 
(Renard, 1980; Schiffman, 1983), occasioning pressure on local officials by developmental and conservative interests. Zoning decided at local level appears as a political compromise (Senecal et al., 2001).

Finally, we showed that decentralisation has also increased the heterogeneity of local implementation: rules now vary, both between municipalities and between regions (Italy) or départements (France). This spatial heterogeneity of regulations creates new social inequalities among farmers and between farmers and non-farmers regarding access to farmland, housing and building rights. Farmland conversion has thus persisted despite the stronger regulatory constraints in agricultural areas, partly because their implementation was poorly accepted and engendered conflicts and feelings of injustice. In Rome particularly, decentralisation worsened the lack of legitimacy and reliability of planning policies, and administrative shortcomings legitimised continued illegal practices. Around Montpellier, the regulatory sanctuarisation of some agricultural areas, while better protecting farmland, gave rise to conflicts between State services, municipalities and farmers. Nor does it guarantee the pursuit of farming and its orientation towards multifunctional peri-urban agriculture.

These shortcomings in a hierarchical mode of governance within a decentralised institutional framework have in recent years led to alternative local initiatives and new modes of governance. In this second stage, decentralisation probably has more potential advantages than disadvantages. It provides better opportunities for decision-making participation by local stakeholders. In both cities, decentralisation has favoured innovations all of which have improved farmland preservation. Some offer improvements not only in farmland protection methods but also in methods of maintaining farming on the urban fringe. Similar instruments were introduced in the two cities: enhanced planning documents, agricultural parks, allocation of public land to farmers.

Around Montpellier, consultation over management of construction within agricultural areas took place in an institutional framework maintaining a system of 'co-management' restricted to negotiations between State and farmers, confirming what Muller (2000) found at other decision levels in France. Innovative solutions proposed within this framework - département working groups, SCOT, agripark, grouping of farm buildings - all improved the effectiveness of protection of peri-urban farmland. This form of co-governance also facilitated control for the State, but it did not address the new societal demands for multifunctional peri-urban agriculture. Moreover, it improved the social acceptability of farmland protection only for the stakeholders involved in the negotiations: the leading farmers' unions and the winegrowing sector. Local authorities failed to bring in new faces; participation was not open to all agricultural actors nor to civil society. Therefore, this form of co-governance generated new social tensions and inequalities among farmers and between farmers and other residents, raising issues of social and spatial equity. New modes of governance thus do not automatically ensure improved social acceptability of public policy.

Around Rome, citizen participation is stronger than around Montpellier. Community or civil society organisations seeking the preservation of the Agro Romano have lobbied the municipality to reinforce regulatory protection of agricultural zones and to promote multifunctional peri-urban agriculture through the allocation of public land and agricultural parks. The effectiveness of the attempt at selfgovernance we observed - the agricultural park of Casal del Marmo still depends on adequate public support. Past shortcomings in regulatory enforcement and the current lack of funding have so far undermined the reliability of public action. The social acceptability of such initiatives is boosted by the involvement of citizens under provisions for public consultation or civil society movements. Similar social movements have been observed around Milan (Branduini and Scazzosi, 2011). A rural renaissance can be observed throughout Italy under the economic crisis (Poli Editoriale., 2013), emerging from local community groups federating within national movements such as Genuino
Clandestino, ${ }^{6}$ supporting for instance the allocation of public land to farmers in many regions. Around Rome, we observed that the social movements which combat large-scale public or private urban projects planned in agricultural areas bring together diverse interests - residents protecting their living environment, alternative farmers, citizens opposed to real estate 'deals'. This finding confirms what scholars found in Canada (Spalling and Wood, 1998), in the USA (Bunce, 1998) or in Israel (Feitelson, 1999): the coalitions that support farmland protection are formed by stakeholders of heterogeneous nature.

Through such alternative local initiatives, decentralisation did positively impact the effectiveness of farmland protection instruments, by increasing government officials' sensitivity and responsiveness to local needs. In some cases, it also helped to address the multifunctionality of agriculture beyond the issue of farmland protection. Concerning social acceptability, decentralisation provides better opportunities for decision-making participation by local non-public stakeholders, thereby enhancing the legitimacy of farmland protection instruments. However, public consultation may also increase conflict when some actors are excluded. Our results thus confirm that stakeholder-based approaches are complex to implement when they involve numerous, diverse stakeholders with conflicting interests (Cormerais-Thomin and Bertrand, 2013, Rey-Valette et al., 2014). Participatory governance does not always foster social acceptability.

Our analytical framework based on effectiveness and social acceptability has helped us assess different modes of governance, and it revives the long-standing debate on efficiency vs. equity in farmland protection (Jacobs, 1989). It should be used to analyse other local initiatives, to further test and potentially improve its heuristic power. The definitions of effectiveness and social acceptability used here come from the literature. However, it would be interesting to analyse how local stakeholders themselves define effectiveness and social acceptability related to local initiatives for farmland protection. Such a constructivist approach could shed light on the rationales behind decisions and the barriers to social acceptability, helping to build a local consensus on the goals and the instruments of farmland protection. New tools for increased public awareness, recruitment and dialogue are needed if the aim of participation is to include numerous and diverse stakeholders (Margerum, 2005). A participatory method based on focus groups was, for instance, used by Kerselaers et al. (2011) to set priorities for agricultural land preservation with local stakeholders.

Kooiman's governance framework proved helpful here in evaluating the impact of decentralisation. First, his three notions of 'image', 'instruments' and 'actions' were useful to understand the role played by instrumentation in farmland protection policies. For instance, they highlighted how the overarching goal of farmland protection was translated into instruments such as reinforced regulatory constraints concerning construction in agricultural areas at national and at some lower levels (depending on local authorities). But this was not always followed by the expected actions, because of the interplay between local stakeholders within a decentralised institutional framework.

Second, we used Kooiman's three major modes of governance to illustrate the main patterns of evolution from a hierarchical governance to new modes of governance, closer to co-governance around Montpellier and to self-governance around Rome. There is, however, a risk that such a typology may mask the diversity within each type. For instance, the Casal del Marmo agricultural park was an attempt at, rather than an illustration of, self-governance. Based on Muller (2000), we characterised as co-management the co-governance mode restricted to negotiations between State representatives and farmers around Montpellier. Kooiman himself (2003) distinguishes a variety of configurations within each of his three types, especially under co-governance. Although it is beyond the scope of this paper, a more systematic analysis of the governance structure in alternative initiatives would be

\footnotetext{
${ }^{6}$ http://genuinoclandestino.it/.
} 
interesting as a further test of Kooiman's governance framework.

\section{Conclusion}

Our hypothesis was that decentralisation processes have changed ways of governing, introducing new modes of governance that have had an impact on the effectiveness and social acceptability of farmland protection.

Our results show that decentralisation first lowered the effectiveness and the social acceptability of a hierarchical mode of governance of farmland protection. This is because multiple decision-making levels increased the complexity of procedures, because there was spatial heterogeneity in implementation and because behaviours skirting the law were reinforced by the proximity between local officials and landowners and developers. However, decentralisation also favoured local alternative initiatives for farmland protection and farming development on the urban fringe. New modes of governance emerged, closer to co-governance around Montpellier and to self-governance around Rome. These new modes of governance often improved the effectiveness of farmland protection and introduced new issues into local debates, centred around ways not only to protect farmland but also to maintain farming and possibly foster its multifunctionality, in line with societal demands from city dwellers. The social acceptability of these new modes of governance varies, depending on who is really included in the participation process. Only the self-governance mode could theoretically solve the legitimacy and social acceptability issues connected with public policies, because civil society actors are in charge. However, self-governance proved difficult to implement in the case of the Casal del Marmo agricultural park in Rome. The social acceptability of public policies implemented through co-governance is more uncertain, because it depends on negotiations and power relationships between stakeholders.

Our study is limited to comparing how the two city regions of Montpellier and Rome have implemented farmland protection instruments, encompassing not only the regulatory framework but also alternative initiatives. This comparison allowed us to clarify the ambivalent impacts of decentralisation and the overall trend towards new modes of governance, while underlining the path-dependency related to each institutional framework. However, each initiative deserves a more in-depth study of its governance mode. Beyond his three major modes of governance, Kooiman's distinction between 'interferences' in primary societal processes, horizontal 'interplays', and vertical, formalized 'interventions' points to worthwhile directions for further research. It would also be interesting to consider how local stakeholders themselves define effectiveness and social acceptability related to local initiatives for farmland protection.

There are at least two lessons for planners and policy makers here. First, our study of alternative local initiatives shows that a successful participatory approach requires new governance tools for increased public awareness, recruitment and dialogue to include numerous and diverse stakeholders. This is a learning process, requiring the training of the stakeholders or external support. Moreover, considering the specific constraints that farmers are facing on urban fringes, farmland protection will probably not be enough to maintain farming and foster its multifunctionality without a local market to support farmers' remuneration and preserve the diverse uses of farmland.

Second, our results show that some public supervision is still required when planning powers are devolved to local authorities, in order to harmonise local implementation and to combat free-rider behaviour, skirting the law, and preferential treatment by the authorities. For instance, in France, since 2010, a new regulatory authority (CDPENAF) at département level has controlled and limited farmland conversion stemming from local authorities' decisions. In both countries recently, more powers have also been given to intermunicipal bodies to enable them to withstand pressure from individual or group interests. The effectiveness of such public supervision would, however, require adequate financial resources, even in cases of co- or self-governance. This is a challenge in a European context of public budget reductions.

\section{Acknowledgements}

The authors acknowledge the French National Research Agency (ANR) funding via the JASMINN project $n^{\circ}$ ANR-14-CE18-0001.

\section{References}

Abrantes, P., Soulard, C., Jarrige, F., Laurens, L., 2010. Dynamiques urbaines et mutations des espaces agricoles en Languedoc-Roussillon (France). European Journal of Geography, Cybergeo. http://dx.doi.org/10.4000/cybergeo.22869. http://cybergeo. revues.org/22869.

Alfasi, N., Almagor, J., Benenson, I., 2012. The actual impact of comprehensive land-use plans: insights from high resolution observations. Land Use Policy 29 (4), 862-877. http://dx.doi.org/10.1016/j.landusepol.2012.01.003.

Alterman, R., 1997. The challenge of farmland preservation: lessons from a six-nation comparison: American Planning Association. J. Am. Plann. Assoc. 63 (2), 220-243.

Altes, W.K.K., 2009. Taxing land for urban containment: reflections on a Dutch debate. Land Use Policy 26, 233-241. http://dx.doi.org/10.1016/j.landusepol.2008.01.006. Artmann, M., 2014. Institutional efficiency of urban soil sealing management - from raising awareness to better implementation of sustainable development in Germany. Landscape Urban Plann. 131, 83-95. http://dx.doi.org/10.1016/j.landurbplan.2014. 07.015 .

Beetham, D., 1991. The Legitimation of Power. Basingstoke, Royaume-Uni de GrandeBretagne et d'Irlande du Nord., Palgrave Macmillan.

Bengston, D.N., Fletcher, J.O., Nelson, K.C., 2004. Public policies for managing urban growth and protecting open space: policy instruments and lessons learned in the United States. Landscape Urban Plann. Soc. Aspects Landscape Change: Protect. Open Space Under Pressure Dev. 69 (2-3), 271-286. http://dx.doi.org/10.1016/j. landurbplan.2003.08.007.

Branduini, P., Scazzosi, L., 2011. Les paysages agraires périurbains: vers la co-construction du territoire. Urbia 12 (Juin).

Bren d'Amour, C., Reitsma, F., Baiocchi, G., Barthel, S., Güneralp, B., Erb, K.-H., Haberl, H., Creutzig, F., Seto, K.C., 2016. Future urban land expansion and implications for global croplands. PNAS 201606036. http://dx.doi.org/10.1073/pnas.1606036114.

Bryant, C.R., Johnston, T.R., 1992. Agriculture in the City's Countryside. University of Toronto Press, Toronto; Buffalo.

Bunce, M., 1998. Thirty years of farmland preservation in North America: discourses and ideologies of a movement. J. Rural Stud. 14, 233-247. http://dx.doi.org/10.1016/ S0743-0167(97)00035-1.

Cadène, P., 1990. L'usage des espaces péri-urbains: une géographie régionale des conflits. Études Rurales 235-267.

Cavallo, A., Marino, D., 2012. Understanding changing in traditional agricultural landscapes: towards a framework. J. Agric. Sci. Technol. B 2, 971-987.

Cormerais-Thomin, R., Bertrand, N., 2013. La mise en œuvre des corridors écologiques: de la concertation locale à l'inscription foncière communale. Développement durable et territoires. Économie, géographie, politique, droit, sociologie 4 (February (1)). http://dx.doi.org/10.4000/developpementdurable.9712.

Crozat, D., 2009. La production culturelle de la norme spatiale à travers l'habitat illégal dans l'Hérault. Géogr. Cult. 43-62. http://dx.doi.org/10.4000/gc.2217.

Daniels, T., Lapping, M., 2005. Land preservation: an essential ingredient in smart growth. J. Plann. Lit. 19 (3), 316-329.

Darly, S., Torre, A., 2013. Conflicts over farmland uses and the dynamics of agri-urban localities in the Greater Paris Region: an empirical analysis based on daily regional press and field interviews. Land Use Policy 33, 90-99. http://dx.doi.org/10.1016/j. landusepol.2012.12.014.

Di Donato, B., Perrin, C., Cavallo, A., 2016. Strumenti di gestione dell'agricoltura urbana e periurbana: esperienze a confronto tra Roma e Montpellier. Agriregionieuropa 12 (44), 59-62.

Feitelson, E., 1999. Social norms, rationales and policies: reframing farmland protection in Israel. J. Rural Stud. 15, 431-446. http://dx.doi.org/10.1016/S0743-0167(99) 00013-3.

Fournis, Y., Fortin, M.-J., 2017. From social acceptance to social acceptability of wind energy projects: towards a territorial perspective. J. Environ. Plann. Manage. 60, 1-21. http://dx.doi.org/10.1080/09640568.2015.1133406.

Gibelli, M.-C., Salzano, E., 2006. No Sprawl: perche è necessario controllare la dispersione urbana e il consumo di suolo. Alinea, Florence.

Gosnell, H., Kline, J.D., Chrostek, G., Duncan, J., 2011. Is Oregon's land use planning program conserving forest and farm land? A review of the evidence. Land Use Policy 28, 185-192. http://dx.doi.org/10.1016/j.landusepol.2010.05.012.

Holtslag-Broekhof, S.M., Beunen, R., van Marwijk, R., Wiskerke, J.S.C., 2014. 'Let's try to get the best out of it' understanding land transactions during land use change. Land Use Policy 41 (November), 561-570. http://dx.doi.org/10.1016/j.landusepol.2014. 04.016.

Jacobs, H.M., 1989. Social equity in agricultural land protection. Landscape Urban Plann. 17 (1), 21-33. http://dx.doi.org/10.1016/0169-2046(89)90064-9.

Jacobs, H.M., 2008. The future of the regulatory takings issue in the United States and europe: divergence or convergence? The Urban Lawyer 40 (1), 51-72.

Jarrige, F., Perrin, C., 2017. L'agriparc : une innovation pour l'agriculture des territoires urbains ?. Revue d'Économie Régionale \& Urbaine. Juin 2017 (3), 537-562. http:// dx.doi.org/10.3917/reru.173.0537. 
Jarrige, F., Jouve, A.M., Napoleone, C., 2003. Et si le capitalisme patrimonial foncier changeait nos paysages quotidiens? Courr. environ. INRA 49, 13-29.

Johnson, M.P., 2001. Environmental impacts of urban sprawl: a survey of the literature and proposed research agenda. Environ. Plann. A 33, 717-735. http://dx.doi.org/10. 1068/a3327.

Jouve, A.-M., Vianey, G., 2012. Le foncier: une ressource territoriale difficile à construire en périurbain. Écon. Rurale 330-331, 27-41.

Kerselaers, Eva, Rogge, Elke, Dessein, Joost, Lauwers, Ludwig, Van Huylenbroeck, Guido, 2011. Prioritising land to be preserved for agriculture: a context-specific value tree. Land Use Policy 28 (1), 219-226. http://dx.doi.org/10.1016/j.landusepol.2010.06. 003.

Kerselaers, E., Rogge, E., Vanempten, E., Lauwers, L., Van Huylenbroeck, G., 2013. Changing land use in the countryside: stakeholders' perception of the ongoing rural planning processes in flanders. Land Use Policy 32, 197-206. http://dx.doi.org/10. 1016/j.landusepol.2012.10.016.

Kjær, A.M., 2004. Governance. Royaume-Uni de Grande-Bretagne et d'Irlande du Nord., Cambridge, UK.

Kline, J.D., Thiers, P., Ozawa, C.P., Yeakley, J.A., Gordon, S.N., 2014. How well has landuse planning worked under different governance regimes? A case study in the Portland, OR-Vancouver, WA metropolitan area, USA. Landscape Urban Plann. 131 (November), 51-63. http://dx.doi.org/10.1016/j.landurbplan.2014.07.013.

Kooiman, J., Bavinck, M., Chuenpagdee, R., Mahon, R., Pullin, R., 2008. Interactive governance and governability: an introduction. J. Transdisciplinary Environ. Stud. 7.

Kooiman, J., 2003. Governing as Governance. Sage.

Koomen, E., Dekkers, J., van Dijk, T., 2008. Open-Space preservation in the Netherlands: planning practice and prospects. Land Use Policy 25 (3), 361-377. http://dx.doi.org/ 10.1016/j.landusepol.2007.09.004.

Lichtenberg, E., Ding, C., 2008. Assessing farmland protection policy in China. Land Use Policy 25 (1), 59-68. http://dx.doi.org/10.1016/j.landusepol.2006.01.005.

Madeline, P., 2006. L'évolution du bâti agricole en France métropolitaine: un indice des mutations agricoles et rurales. Inf. géogr. 70 (3), 33-49.

Millward, H., 2006. Urban containment strategies: a case-study appraisal of plans and policies in Japanese British, and Canadian cities. Land Use Policy 23, 473-485. http://dx.doi.org/10.1016/j.landusepol.2005.02.004.

Muller, P., 2000. La politique agricole française: l'État et les organisations professionnelles. Économie Rurale. $N^{\circ}$ 255-256. Les Cinquante Premières Années De La Sfer. Quel Avenir Pour l'économie Rurale? pp. 33-39. http://dx.doi.org/10.3406/ ecoru.2000.5153.

Nelson, A.C., Moore, T., 1996. Assessing growth management policy implementation: case study of the United States' leading growth management state. Land Use Policy 13, 241-259. http://dx.doi.org/10.1016/0264-8377(96)84555-8.

Nelson, A.C., 1992. Preserving prime farmland in the face of urbanization - lessons from oregon. J. Am. Plann. Assoc. 58 (4), 467-488. http://dx.doi.org/10.1080/ 01944369208975830 .

Nougarèdes, B., 2013. Modes d'insertion socio-spatiale du bâti agricole périurbain et sociabilités locales. Le Cas Des « Hameaux Agricoles » Dans l'Hérault, Thèse De Doctorat De Sociologie, vol. 2 Toulouse 2 Le Mirail (469, 152 p.).

Nougarèdes, B., 2015. La Gestion Durable Du bâti Agricole périurbain: Gouvernance Et Enjeux Locaux. Le cas des « hameaux agricoles » dans l'Hérault. Analyses du Centre d'étude et de prospectives du Ministère de l'agriculture, de l'alimentation et de la forêt. n ${ }^{\circ}$ 81, pp. 7. (mai 2015). http://agriculture.gouv.fr/telecharger/73524? token $=$ b8aaec $6 \mathrm{ca} 2 \mathrm{~cd} 053 \mathrm{~d} 2 \mathrm{da} 520284 \mathrm{f} 6127 \mathrm{c} 0$.

Pellegrino, D., Marino, D., 2016. Il Parco agricolo di Casal del Marmo. Un sistema ecologico, agricolo e alimentare resiliente per Roma. Agriregionieuropa 44, 73-75.

Perrin, C., Jarrige, F., Soulard, C.T., 2013. L'espace et le temps des liens ville-agriculture: une présentation systémique du cas de Montpellier et sa région. Cahiers Agric. 22 (6), $552-558$.

Plieninger, T., Draux, H., Fagerholm, N., Bieling, C., Bürgi, M., Kizos, T., Kuemmerle, T., Primdahl, J., Verburg, P.H., 2016. The driving forces of landscape change in Europe: a systematic review of the evidence. Land Use Policy 57, 204-214. http://dx.doi.org/ 10.1016/j.landusepol.2016.04.040.

Poli Editoriale, D., 2013. Problematiche e strategie per il ritorno alla terra. Sci. Terr. 1, 17-42.

Renard, V., 1980. Plans d'urbanisme et justice foncière. Presses universitaires de France, impr., Paris, France.

Rey-Valette, H., Chia, E., Mathé, S., Michel, L., Nougarèdes, B., Soulard, C., Maurel, P., Jarrige, F., Barbe, E., Guiheneuf, P.-Y., 2014. Comment analyser la gouvernance territoriale? Mise à l'épreuve d'une grille de lecture, Géographie, Économie. Société 16 (2014), 65-89 (26p).

Salvati, L., Munafo, M., Morelli, V.-G., Sabbi, A., et al., 2012. Low-density settlements and land use changes in a Mediterranean urban region. Landscape Urban Plann. 105 (1-2), 43-52.

Salvati, L., 2013. Urban containment in action? Long-term dynamics of self-contained urban growth in compact and dispersed regions of southern Europe. Land Use Policy 35, 213-225. http://dx.doi.org/10.1016/j.landusepol.2013.05.009.

Scazzosi, L., Branduini, P., 2014. Paesaggio e fabbricati rurali, suggerimenti per la progettazione e la valutazione paesaggistica. MIBACT, Maggioli editore.

Schiffman, I., 1983. Saving california farmland: the politics of preservation. Landscape Plann. 9 (3-4), 249-269 16/0304-3924(83)90006-0.

Schneider, A., 2003. Decentralization: conceptualization and measurement. St. Comp. Int. Dev. 38, 32-56. http://dx.doi.org/10.1007/BF02686198.

Senecal, G., Pierre, J.H., Guerpillon, L., Boivin, J., 2001. Aménager la métropole nature: retour sur les efforts passés de planification dans la région de Montréal et essai d'évaluation de la situation actuelle des banlieues. Géocarrefour 76 (4), 303-317. http://dx.doi.org/10.3406/geoca.2001.2572.

Sini, L.X., 2015. Entre Action Publique Et Stratégies Individuelles Pour La Protection Du Foncier Agricole à Rome: Enjeux De Justice Dans Le vécu Des Acteurs 3. Université Paul Valéry, Montpellier, pp. 80 (Encadrement: Moity-Maïzi P., Perrin C.).

Stoker, G., 1998. Governance as theory: five propositions. Int. Soc. Soc. J. 50, 17-28. http://dx.doi.org/10.1111/1468-2451.00106.

Tan, R., Beckmann, V., van den Berg, L., Qu, F., 2009. Governing farmland conversion: comparing China with the Netherlands and Germany. Land Use Policy 26 (4), 961-974. http://dx.doi.org/10.1016/j.landusepol.2008.11.009.

Vallat, C., 1995. Rome Et Ses Borgate, 1960-1980: Des Marques Urbaines à La Ville Diffuse. École Française de Rome, Rome, pp. 236.

Zasada, I., 2011. Multifunctional peri-urban agriculture-a review of societal demands and the provision of goods and services by farming. Land Use Policy 28, 639-648. http:// dx.doi.org/10.1016/j.landusepol.2011.01.008. 